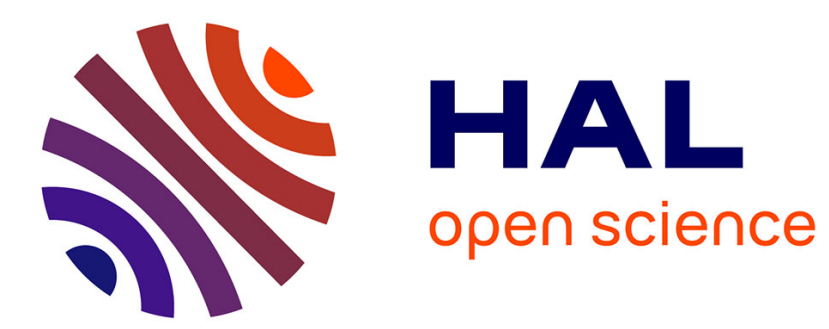

\title{
The Rapanui diaspora in Tahiti and the lands of Pamatai (1871-1970) \\ Diego Muñoz
}

\section{To cite this version:}

Diego Muñoz. The Rapanui diaspora in Tahiti and the lands of Pamatai (1871-1970). Rapa Nui Journal, 2015, 29 (2). hal-01243349

\author{
HAL Id: hal-01243349 \\ https://hal.science/hal-01243349
}

Submitted on 15 Dec 2015

HAL is a multi-disciplinary open access archive for the deposit and dissemination of scientific research documents, whether they are published or not. The documents may come from teaching and research institutions in France or abroad, or from public or private research centers.
L'archive ouverte pluridisciplinaire HAL, est destinée au dépôt et à la diffusion de documents scientifiques de niveau recherche, publiés ou non, émanant des établissements d'enseignement et de recherche français ou étrangers, des laboratoires publics ou privés. 


\title{
The Rapanui diaspora in Tahiti and the lands of Pamatai (1871-1970)
}

\author{
Diego Muñoz
}

When commercial flights between Rapa Nui and Tahiti began in 1968, after nearly 70 years of colonial confinement, a new migratory process began from Rapa Nui to Tahiti. This included claims of ownership of the lands of Pamatai, bought 80 years earlier by a group of 25 Rapanui immigrants. For the Rapanui people, the history of the lands of Pamatai evokes a series of memories and forgotten events, genealogical ties, as well as a constant search for a linkage with Tahiti - a "memory of diaspora."

In this paper, I analyze the history of links between Rapanui people and Tahiti and the role of the lands of Pamatai in the Rapanui migration process: the exodus during the nineteenth century, confinement on Easter Island, the broken link with Tahiti, and Rapanui claims for ownership of the lands of Pamatai after the 1970s.

Cuando comenzaron los vuelos comerciales entre Rapa Nui y Tahiti en 1968, después de 70 años de confinamiento colonial, un nuevo proceso migratorio comenzó desde Rapa Nui hacia Tahiti. Éste incluyó la reivindicación de las tierras de Pamatai, compradas hacía 80 años atrás por un grupo de 25 inmigrantes rapanui. Estas reivindicaciones nos mostraban la perpetuación de una "memoria de diáspora" que unía las dos islas. En Rapa Nui la historia de las tierras de Pamatai evoca una serie de memorias y olvidos, de lazos genealógicos y también de una búsqueda constante de nexos con Tahiti.

En este artículo analizo la historia de dichos vínculos y el rol de las tierras de Pamatai en la migración rapanui. El éxodo del siglo diecinueve, el confinamiento en Isla de Pascua y el quiebre de los vínculos con Tahiti; así como también las estrategias de los rapanui para reivindicar de la propiedad de las tierras después de los años 1970.

\section{Introduction}

"I came in 1972 because of the issue of land belonging to the islanders who came in the late 1800s. They arrived in Tahiti and bought 25 plots, with 118 hectares. That belonged to 25 people from Easter Island. But, most of these lands were stolen, and only a few have recovered it." (Regino Tuki Hotus, Pamatai 2012). ${ }^{1}$

"I had the idea that the land belonged to my father because his grandfather had purchased it [...] and we were on the land for a long time. According to my mother [...] this land had to be divided among six siblings." (Moisés Hereveri Pakarati, Pamatai 2009).

On September 26, 1887, a group of 25 Rapanui immigrants purchased the lands of Pamatai, a 118 hectare ranch located $3 \mathrm{~km}$ southwest of Pape'ete in the district of Faa'a, from the Catholic Church of Tahiti. This event established the historical link between the Rapanui islanders and Tahiti and is associated with memory, religion, kinship, and legal property of lands.
When commercial flights between Rapa Nui and Tahiti began in 1968, after nearly 70 years of colonial confinement, a new migratory process began from Rapa Nui to Tahiti. This included claims of ownership of the lands of Pamatai, showing a continuing "memory of diaspora" (Safran 1991; Clifford 1994; Agnew 2005) that links the two islands.

During my first fieldwork in Tahiti (2009), I counted 104 Rapanui immigrants living in French Polynesia (on Tahiti, Mo'orea, Bora Bora, and Raiatea), of which $41 \%$ live in Pamatai. They all claimed to have ancestors who were buyers of Pamatai lands in 1887. For the Rapanui people, claiming/owning the property of these lands was considered the main reason to settle in Tahiti (Muñoz 2010). However, not all Rapanui immigrants have secured property title over the lands.

During my second research project in Tahiti (20122013), I collected 16 claims filed in the Pape'ete court from 1968 to the present, in which only four cases for land rights were restored, while another seven demands were rejected. There are still five claims in process.

On Rapa Nui in 2011, some islanders who had lived in Tahiti informed me that the ownership of the lands of Pamatai had caused disputes within their

Diego Muñoz | EHESS-AMU-CREDO (UMR 7308),France, diego.munoz@ehess.fr 
families regarding money and frustration for not being recognized as the owners by the Franco-Tahitian courts. Between 2012 and 2013, the Rapanui living in Tahiti reported the same experiences to me.

This paper analyzes the historic period diaspora between Rapa Nui and Tahiti in order to understand why some islanders tried to vindicate the rights over the lands of Pamatai. Some were not recognized as owners, while in other cases, they received recognition. Joining ethnographic work and archival research in both Tahiti and Rapa Nui exposed the fragments of a "memory of diaspora" ( $c f$. Safran 1991; Clifford 1994). According to Agnew (2005:19):

"The concept of the diaspora has been widely adopted in academic discourses on forced dispersal, immigration, displacement, and the establishment of reconfigured transnational communities. Memories are the glue that holds the past and present together."

In addition to that, Agnew (2005:3) explains: of Rapanui fled in small boats to Tahiti between 1947 and $1958 .^{2}$

Nevertheless, the story of the 25 buyers of the lands of Pamatai is a complex history of inheritance rights, land occupation, and the relation of these processes within the French civil code. By 1968, much of the lands of Pamatai had been allocated to other people, including some descendants of the Rapanui buyers of 1887.

For the conclusion of this paper, I discuss Rapanui strategies to claim land ownership with "nonnegotiable self-definition status" (Dousset 2003; Saura 2008) of Rapanui people as "legitimate genealogical heirs", instead of as Tahitians who had acquired rights to the land according to the French civil code. This paper illustrates that only those Rapanui people who maintained links with the Catholic Mission of Tahiti have managed to "recover" property rights to the lands of Pamatai.

\section{The Great Exodus of 1871 and Other Rapanui Migrants}

The conflict between Jean Baptiste Onésime DutrouBornier and missionaries of the Sacré Cours $d u$ Picpus for the purchase of lands, and the problematic settlement of the population to only one village, ended with the missionaries leaving Rapa Nui; not alone, but with more than half of the population in June 1871 ( $c f$. McCall 1976a; Anguita 1986; Fischer 2005).

Patricia Anguita (1986:109) points out that as early as March 1871, John Brander - a landowner in Tahiti and founder of an agricultural-livestock "empire" (Gossler 2005) - had transported a total of 65 islanders to his plantation in Haapape, Tahiti (Table 1). However, the great exodus of Rapanui people would take place on June 6, 1871. On that occasion, Roussel and DutrouBornier managed to board a total of 277 islanders on the ship Sir John Burgoyne, owned by Brander (cf. Cools

Table 1. Rapanui transported in 1871.

\begin{tabular}{|c|c|c|c|c|c|}
\hline & \multicolumn{2}{|c|}{ Dates } & \multirow[t]{2}{*}{ Ship } & \multirow[t]{2}{*}{ Itinerary } & \multirow[t]{2}{*}{ Disembarking } \\
\hline & Started & Arrived & & & \\
\hline \multirow[t]{5}{*}{1871} & & March 9 & Marama & Rapa Nui to Tahiti & $\begin{array}{l}\text { Mr. and Ms. Brander } \\
\text { and } 28 \text { immigrants }\end{array}$ \\
\hline & & March 18 & Mahina & Rapa Nui to Tahiti & 37 immigrants \\
\hline & June 6 & $\begin{array}{l}\text { June } 23 \\
\text { (Gambier) }\end{array}$ & Sir John Burgoyne & $\begin{array}{l}\text { Rapa Nui to Gambier } \\
\text { and Tahiti }\end{array}$ & 168 immigrants to Gambier \\
\hline & & July 4 (Tahiti) & & & 109 immigrants to Tahiti \\
\hline & & October 6 & Sir John Burgoyne & Rapa Nui to Tahiti & 67 immigrants \\
\hline Total: & & & & & 409 immigrants \\
\hline
\end{tabular}


1973:ms445:174; Anguita 1986). Of these, 168 landed on Mangareva with Roussel, while the other 109 went to Tahiti with Brother Théodule Escolan. Those who traveled with Escolan were incorporated as plantation workers in Brander's Haapape lands. In October 1871, Dutrou-Bornier sent 67 islanders to join the workers of Brander. Anguita (1986:114) claims that all of them had "signed" employment contracts for periods of three to five years to work for Brander.

Grant McCall (1986:7) estimates that by 1870, the population of Rapa Nui was around 600 inhabitants. Subtracting the 409 persons who were transported to Tahiti and Mangareva in 1871, we estimate that only 191 people were living on Rapa Nui at that time. In 1877, Alphonse Pinart (1999 [1878]) reported 110 inhabitants living on the island; this would be the minimum demographic number in the history of Easter Island $^{3}$. Dutrou-Bornier continued to send workers to Brander's plantations, but was aware that he needed workers on the island for his livestock pursuits. Therefore, he sent only four islanders in 1872, and three in 1877 (Table 2; Anguita 1986:112-13).

The last exodus from Rapa Nui toward Tahiti was after the Chilean annexation took place. In November 1888, seven Rapanui people left Easter Island with Alexander Salmon and John Brander Jr., when they finished their work on the island (Toro 1893). Later, at least one islander left Rapa Nui with the priest George Eich in $1898^{4}$. After that, there was no documented immigration between Rapa Nui and Tahiti until the first years of the twentieth century. This is mainly because the Chilean government had banned the islanders from leaving Rapa Nui, a situation that would last for over half a century. There would be only two documented exceptions: in 1926, with the arrival of the schooner Moana, and between 1944 and 1958, when some Rapanui men escaped in small boats (Englert 1960; McCall 1997; Peteuil 2004).

\section{Mortality in Haapape}

"20 minutes from here is a large cotton plantation where all the inhabitants of Easter Island were transported to Tahiti last year to work. There were about 210 transported. The population was highly decimated by high mortality, either because of climate change, or by poor nutrition and illtreatment. There were 52 deaths since they arrived (that is to say) a quarter." (George Eich to TRP Bousquet. June 21, 1872, in Cools 1973:ms468:182).

The Priest George Eich was in charge of the parish of Haapape in 1872 and he was the closest person to the expatriates. In the parish's books, Eich recorded marriages, births, baptisms, and the deaths of Brander's employees. Those documents show that the Rapanui population suffered a high rate of mortality shortly after arriving to Tahiti. For example, in the parish of Mahina, 69 deaths were noted between June 1871 and November 1873 (Cools 1975:ms24-26:282-283). By October of that year, Eich reports a total of 95 dead in Haapape (Cools 1973:ms477:187).

These records also highlight information about survival of expatriates and some births. Several of the worker's names in Haapape appear in the next decade on the lands of Pamatai, Tahiti, and of those in Varari, Mo'orea, both belonging to the Catholic Mission. It is possible that when contracts with Brander expired, the Rapanui worked for the missionaries in Tahiti and Mo'orea (Anguita 1986; Muñoz 2014).

In both places, survivors managed to articulate a fairly cohesive community through the Catholic religion. As many of the territories of the French protectorate were predominantly Protestant (Barré 1987), this perhaps explains the maintenance of the Rapanui Catholic community as a distinct group from the Polynesian Protestants.

Table 2. Rapanui transported between 1872 and 1877.

\begin{tabular}{|c|c|c|c|c|c|}
\hline & $\begin{array}{l}\text { Dates } \\
\text { Arrived }\end{array}$ & Ship & Itinerary & Disembarking & Source \\
\hline \multirow[t]{2}{*}{1872} & October 10 & Marama & Valparaíso to Tahiti & 2 “indigenes" & $\begin{array}{l}\text { Messenger de Tahiti } \\
\text { October } 12,1872\end{array}$ \\
\hline & May 15 & Ionia & $\begin{array}{l}\text { Sydney, Rapa Nui } \\
\text { to Tahiti }\end{array}$ & 2 “indigenes" & $\begin{array}{l}\text { Messenger de Tahiti } \\
\text { May 22, } 1872\end{array}$ \\
\hline 1877 & November 2 & Marama & Rapa Nui to Tahiti & 3 "indigenes" & $\begin{array}{l}\text { Messenger de Tahiti } \\
\text { November } 9,1877\end{array}$ \\
\hline Total: & & & & 7 insulars & \\
\hline
\end{tabular}




\section{Survival in Pamatai}

The first Rapanui people to settle in Pamatai were possibly 14 immigrants that arrived with Roussel from Mangareva in 1872 (Anguita 1986). Documents found in the archives of the Bishop of Tahiti showed that from 1873 on, Rapanui immigrants in Pamatai rented land and worked for the Bishop Tepano Jaussen.

Work contract.

Among the cosigners were the Bishop of Axieri, residing in Papeete, and the Polynesian [océanien]: "Petero a Kitina" from Easter Island. The following agreement was made: the Polynesian [océanien]: "Petero a Kitina" [...] shall perform all work that will be ordered [...] Seen and approved: Papeete June 16, 1875. (ArchEvêché: nº 1 24-1-4-6).

In 1886, Bishop Jaussen wrote the first purchase contract of the lands of Varari, Mo'orea and in Pamatai, Tahiti. In this draft, Jaussen attached a list of the names of 31 Rapanui who would buy land in Pamatai and 12 who would purchase land in Varari (Figure 1).

On September 26, 1887, only 25 Rapanui immigrants were given land. On February 25, 1888, it was divided into 25 individual plots, leaving only two plots as collective property. A small strip "entre la route de ceinture et la mer" [between the road and the sea] and "la parcelle indiquée au plan ci-annexée par les lettres $A B C D$ sera egalement commun pour recevoire l'Eglese, l'école, le cimetière et la maison de reunion de comparants" [a plot marked with the letters ABCD to construct the church, school, cemetery and the meeting house of the buyers] (Acte de Partage du Domaine de Pamatai 1888:4. V॰4 f149). Pamatai property was not subject to collective tenure. A land map with the buyers' names was attached to each plot (Figure 2). It is interesting to note that the names of the plots correspond to places on Rapa Nui (McCall 1976a:349; Muñoz 2014).

In comparing the names on Jaussen's list with the list of owners of 1888 , we find it reveals that the 25 buyers are the Rapanui people already settled in Pamatai before 1886 (such as Karepare Aopero or Mikaera Tearahiva), as well as the workers of Brander (such as Akutino Hereveri or Petero Mati), while others came from the Varari colony (such as Kinitiko Hukihiva), and probably others from Mangareva. This transformed Pamatai into a true Rapanui enclave on Tahiti.

Anguita (1986) explains that the Rapanui people of Pamatai were organized in two agricultural cooperatives. Thanks to documents found in the archives of the Bishop in Pape'ete, it is clear that some Rapanui rented land to Chinese immigrants, while others worked in Pape'ete's port (Stolpe 1899). However, squalid living conditions, disease, high mortality, and low birth rates shaped the future of this colony.

The report of the doctor Jean Nadeaud recorded a total of 15 leprosy patients in 1895 (McCall 1976a:350). In 1897, the German ethnologist Arthur Baessler (1900:84) reported that only "20 men, 11 women and 13 children" lived in Pamatai, and apparently many had leprosy.

This low number of Rapanui people in Pamatai was also due to the return migration to Easter Island of at least 15 islanders after the annexation of the island to Chile (McCall 1976a). ${ }^{5}$ Another 15 Rapanui islanders left Tahiti in the following year (Toro 1893). Finally, it is very probable that another group returned to Rapa Nui in 1898, during the visit of the Priest George Eich. ${ }^{6}$ This would be the last return migration from Tahiti to Rapa Nui that took place during the XIX century.

Table 3. Buyers in Pamatai and Mo‘orea, Jaussen's list of names, 1886: ArchEvêché Tfa Pam:6-9.

\begin{tabular}{|c|c|c|c|c|}
\hline \multicolumn{5}{|c|}{ Rapanui in Pamatai } \\
\hline Kerepare Aopero & Hute Terea & Tepano Hakarevavera & Onorato Takiaora & Ioane Pua Kava \\
\hline Rataro Tuumatahi & Tepano Roma & Nikodemo Pova & Naporeo Puna & Adriano Pua \\
\hline Tanirao Amoaha & Petero Mati & Mateo Tauahanga & Jeremi Regavaruvaru & Mikaera Hinanironiro \\
\hline Leone Tekena & Tamuera Taiva & Papiano Tupaahotu & Mikaere Tarahiva & Timione Veroauka \\
\hline Anatonio Aringa & Matia Manu & Ruka Ago & Makere Tege & Juliano Tupa \\
\hline Petero Tepuku & Ioane Harekiragi & Ioane Torometi & Kinitino Make & Akutino Hereveri \\
\hline Petero Ararua & & & & \\
\hline \multicolumn{5}{|c|}{ Rapanui on Mo'orea } \\
\hline Romepo Apotea & Timoteo Manueono & Mareko Anakena & Tavero Moho & Kinitino Hukihiva \\
\hline Hiripa Puruara & Eukenio Kerimuti & Tavara Haupako & Raimuto Araki & Kinitino Temanu \\
\hline Iope Hotononoi & Anatarea Tepuku & & & \\
\hline
\end{tabular}




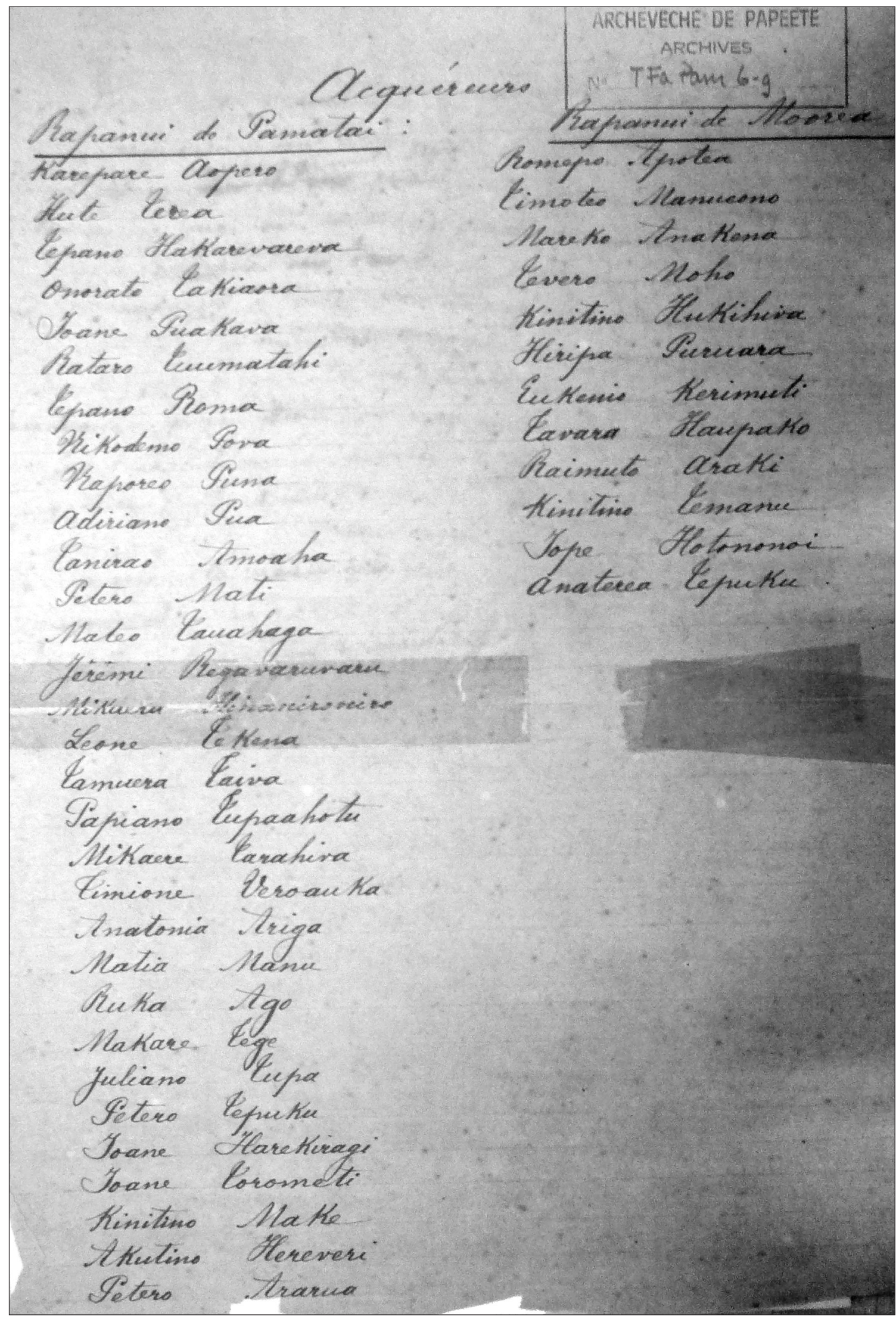

Figure 1. Acquéreurs. Jaussen list of names, 1886: ArchEvêché: Tfa Pam:6-9. 


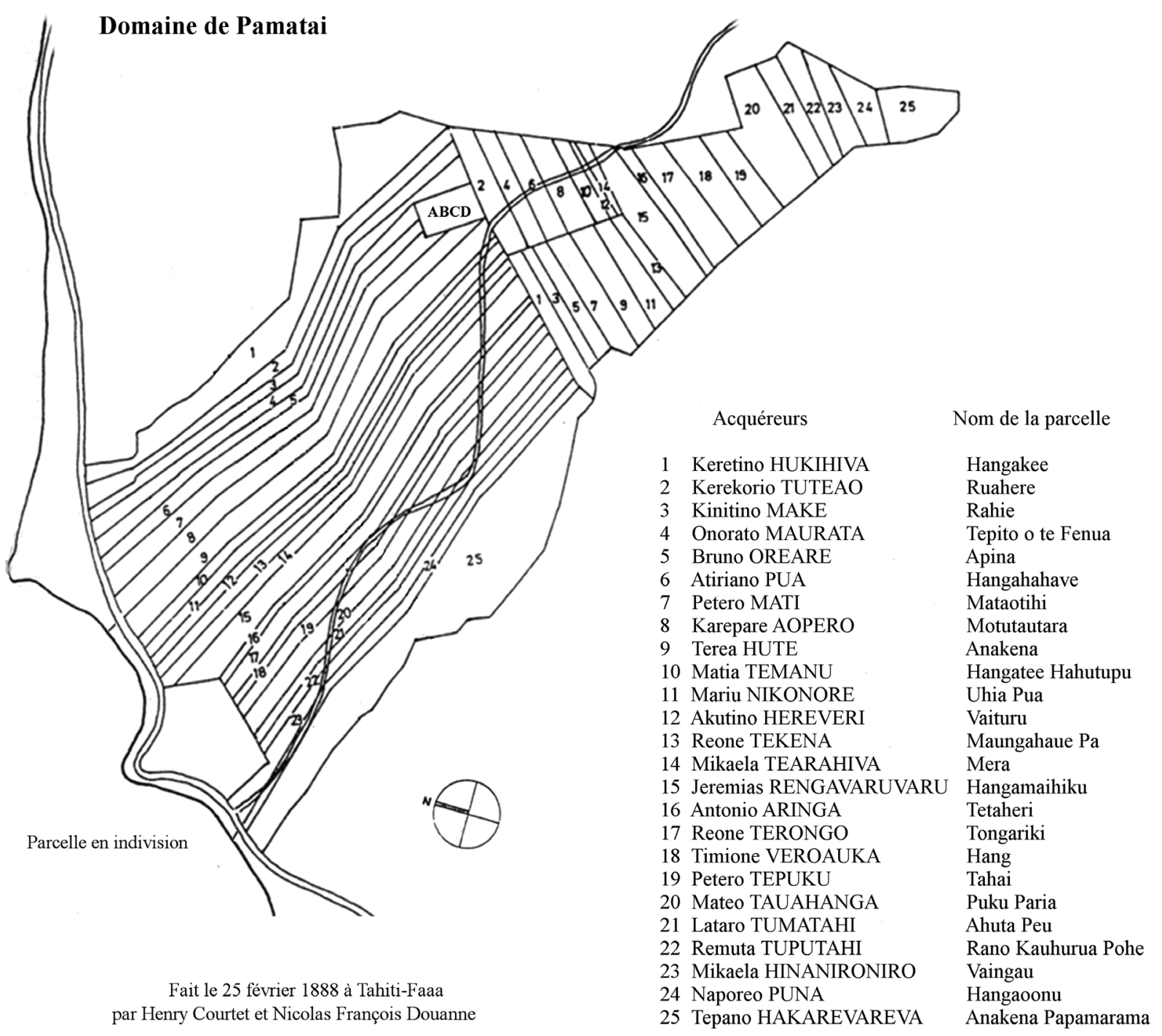

Figure 2. Map of the landowners in Pamatai, 1888. Redrawn by the author, based on Conte 1994 and the copy of the original map (Direction des Affaires Foncières, Pape'ete).

\section{Rapanui Descendants in Tahiti and Ownership of the Lands of Pamatai}

Anguita (1986) concludes that the few survivors of Pamatai inevitably ended up mixing with the other Polynesian population (such as the Tahitians and Tuamotuan peoples). By 1921, after a Tahitian land registry was completed, the Rapanui migrant track would be lost. McCall (1976a:350) adds that in 1960, only one Rapanui land owner in Pamatai had left descendants. However, this paper presents a different conclusion: at least five kinship groups in the current Pamatai population have a family background in the nineteenth century Rapanui diaspora, as well five kinship groups in Rapa Nui that are the descendants of one of the 25 buyers of 1887 .

In anotherpublication(Muñoz2014), Ireconstructed the genealogies of the 25 Rapanui that appeared in the list of owners of 1888 and some noted in Jaussen's list (see Table 3). I presented sibling relationships and matrimonial alliances between the Rapanui of Pamatai and Varari and some of their descendants. It is interesting to note that some of these descendants' signatures appeared on the land registry documents in both 1921 and 1951; this proves a succession of property rights. ${ }^{7}$ Specifically, through the analyses of Rapanui genealogies and land registry documents, I identified six procedures by which the ownership of 
these lands was changing over time. This revealed a close link between kinship and land ownership.

For the descendants of the 25 buyers, it was established that:

Fourteen of them had no children and therefore no direct succession rights to their land: Keretino Hukuhiva, Onorato Maurata, Bruno Oreare, Atiriano Pua, Petero Mati, Karepare Aopero, Terea Hute, Mariu Nikonore ${ }^{8}$ Reone Tekena, Mikaera Tearahiva, Antonio Aringa, Reone Terongo, ${ }^{9}$ Timione Veroauka, and Mikaera Hinanironiro.

Four had descendants, but their sons did not have any children (Table 4). Three had living descendants in Pamatai in 1921 (Table 5), five had living descendants on Rapa Nui in 1921 (Table 6) and finally, five families in Pamatai are descendants from the Rapa Nui enclave of the nineteenth century:

Make family: all descendants of Kinitino Make (see Table 5) and Petero Raharoa (see Table 7); Robson family, descendants of Petero Tepuku (see Table 5); and Tikare, Tekurarere, and Faarii families (see Table 7), founded by the daughters of Timoteo Manueono and Anikete Harekirangi (Arikirangi), a Rapanui couple from the colony in Mo'orea.

Table 4. Rapanui descendants that did not have children.

Mateo Tauahanga $m t$ Veronica Ihumako

O Maira Kohotuiti (1878-1879)

- Adriano a Mateo (1880-1886)

A Tepano Ihu Taha (1886-1900)

Lataro Tumatahi $m t$ Maria Tevai

O Otuhi a Tumatai (1861-1871)

Tepano Hakarevareva $m t$ Marie Rima One

○ Piramarama Mure (1882-1898)

Jeremias Rengavaruvaru $m t$ Veri Maori

A Pakarati Renga Varuvaru (1872-1937) $m t$ Teapo Toaia
Land 21

Land 25

Land 15
Legend:

$m t$ Marriage to

$\Delta$ Man

Woman 
Table 5. Rapanui descendants in Pamatai in 1921.

\section{Kinitino Make $m t$ Maria Pua a Vave Land 3}

O Heremeta Make (1874- 1953) [see later]

Inaria Make (1877-1918)

\ Hotu 'a Make (1878-?) $m t$ Teruma Taro (1879- ?)

\ Hotu Make (1909-1934) [poki hāyai of Petero Raharoa] mt Marie Tarahu (1906-1971)]

A Pierre Hotu Make (1832-2005)

Petero Tepuku $w$ Anne Marie Tupuraa Puna $\quad$ Land 19

A Atiapoe Rehu (1892-1948) $m t$ Celestine Hiro Hennebuise (1905-1952)

○ Maria a Rehu (1917-1956) mt John Robson

$\checkmark$ Robson

○ Louise Ahupotu Reoni Puna ( 1873-? ) mt Kerekorio Ruko (1864-1903 )

A Jermias Ruko Aromoai (1887-1918)

○ Luisa Ruko Aromoai (1888-1926)

A Juan Ruko Aromoai (1890-1927)

○ Margarita Ruko Aromoai (1892-1964)

○ Anne Marie Tupuraa Puna (1874- ?) mt Joseph Paehahati (1873- ?) ${ }^{10}$

○ Marie Tupuraa Paehahati (1896-1970) mt Tahiti Tairua

A Clément Amaru Reoni Puna (1876-?) mt Eusebia Teone (1881-1912)

A Amaru Rereao Puna (1912-1957 ) $m t$ Rehia Poheroa

○ Rosina Rereao (1929-)

Legend:

$m t$ Marriage to

$w$ with

- Man

○ Woman

$\checkmark$ Siblings group 
Table 6. Rapanui descendants on Rapa Nui in 1921.

\section{Kinitino Make $m t$ Maria Pua a Vave}

Heremeta Make (1874- 1953) $m t$ Vincent Pont (1866-1946)

A Vicente Pont Make (1896-1971) mt Laura Hill Huki (1903-1963)

- Pont Hill

\section{Kerekorio Tuteao Ruko $m t$ Louise Ahupotu Reoni Puna Land 2}

A Jermias Ruko Aromoai (1887-1918)

○ Luisa Ruko Aromoai (1888-1926)

A Juan Ruko Aromoai (1890-1927)

O Margarita Ruko Aromoai (1892-1964) mt Casimiro Paoa Bornier (1893-1968)

○ Mariana Paoa Ruko (1911-1940) mt Leon Tuki Hei (1908-1990)

- Taverio Tuki Paoa (1928-2004) $m t$ Erea Hotus Atan (1928-?)

$\checkmark$ Tuki Hotus

\section{Matia Temanu $w$ Marate Paru Vaka Hakahira Land 10}

○ Catalina Te Kava Tutia (1863-1930 ?) w Gustave Hennebuise (1843-1935)

- Matias Hotu Temanu (1886-1951) $m t$ Victoria Ika Tetono (1888-1953)

$\checkmark$ Hotus Ika

\section{Akutino Hereveri $m t$ Margarita Te Vai a Tare Land 12}

A Moisés Jacob Tu‘u Hereveri (1873-1925) mt Parapina Uka o Tu'a a Vaka (1870-1927)

$\diamond$ Hereveri [Beriberi] Avaka

Remuta Tuputahi $m t$ Aka Viri

\section{Land 22}

A Remuto Hitorangi (1858-1902) $m t$ Veronica Temanurae (1858-1909)

$\checkmark$ Hito Temanurae

$\checkmark$ Hito Tepihi

- Hito Rapu

- Rapu Hito

$\checkmark$ Pakarati Hito 
Table 7. Families in Pamatai, descendants from Rapanui diaspora.

Petero Raharoa (Petero Make) $m t$ Teuna Tape

- Emilio Paoa Make (1892-1970)

○ Teuna Teri'iti Make [poki hāyai] (1934-1996) $m t$ Salomon Jeremilla

A León Laharoa (1894-1976) $m t$ Anastasia Hei (1896-1934) ${ }^{9}$

$\checkmark$ Laharoa Hei (on Easter Island)

- Romulo Laharoa (1897-1925) (on Easter Island)

○ Vahinetau Make (1897-1962) mt Vahia a Parue Topa (1889-?)

$\checkmark$ Topa

O Meta Make (1907-1956) mt Gabriel Ganapragassam (1903-?)

- Ganapragassam

A Hotu Make (1909-1934) [poki hāyai] mt Marie Tarahu (1906-1971)

A Pierre Hotu Make (1832-2005)

Timoteo Manueono $m t$ Anikete Harekirangi (Arikirangi)

○ Delphine Manueono (1883-1939) mt Raphail Tekurarere (1882-?)

$\diamond$ Tekurarere

O Honoré Agnès Manueono (1885-1937) mt Reti Faarii (1890-1911)

$\checkmark$ Faarii

○ Cécile Manueono (1888-1939) mt Atia Tikare (1886-?)

$\checkmark$ Tikare

Legend:
$m t$ Marriage to
$w$ with
$\boldsymbol{\Delta}$ Man
$\bigcirc$ Woman
$\downarrow \quad$ Siblings group


Regarding the procedures of transfer of property rights, it is identified that:

- Three properties were transferred and divided as inheritance between parents and children:

- Land 3: Owned by Kinitino Make, divided in three plots: Plot 1 for Petero Make [Raharoa], who divided it later for his children Emilio Make, Vahinetau Make, and Meta Make; Plot 2 for Heremeta Make, who sold it to Petero Peckett in 1926; and Plot 3 for Hotu 'a Make, managed by his nephew Emilio Make (see Table 7).

- Land 15: Owned by Jeremias Rengavaruvaru, who gave it to his son Pakarati Rengavaruvaru (see Table 4), who gave it to his godson Pakarati Nuihiva Tauripa (born in 1893 in Pamatai from a Rapanui father and Tahitian mother).

- Land 19: Owned by Petero Tepuku and divided in two plots, one for each of his sons (see Table 5). Plot 1 for Atiapoe 'a Rehu, who gave it to his daughter Maria 'a Rehu; and Plot 2 for Tero 'a Rehu. Atiapoe sold it to Gustave Hennebuise in 1921.

- Six pieces of land were transferred with a testament to other Rapanui or to the Catholic Church:

- Land 5: Owned by Bruno Oreare, who gave it to the Catholic Church.

- Land 17: Owned by Reone Terongo, who gave it to Petero Make [Petero Raharoa].

- Land 20: Owned by Mateo Tauahanga, who gave it to Petero Make [Petero Raharoa] and Andrés Manu a Vaka.

- Land 21: Owned by Lataro Tumatahi, who gave it to Kinitino Make, stating that Make was his brother (fêti ' $i$ ).

- Land 22: Owned by Remuta Tuputahi, who gave half of his land to Adriano Pua and the other half to Bruno Oreare. In 1909, Adriano sold it to Bruno, who gave it to the Catholic Church.

- Land 23: Mikaera Hinanironiro's property, who gave it to Bruno Oreare and Pakarati Rengavaruvaru in 1898. Oreare gave his share to the Catholic Church. Rengavaruvaru gave his share to his godson, Nuihiva Tauripa, who sold it in 1926.

- Four lands were occupied by other Rapanui and their descendants. Two of these lands were given to the occupants under the prescription trentenaire: ${ }^{11}$
- Land 2: Occupied by Anne Marie Tupuraa Puna (Kerekorio Tuteao's sister-in-law) in 1921 and then occupied by Marie Tupuraa Paehahati (daughter of Anne Marie and niece of Kerekorio Tuteao) in 1951. Finally, given to Tupuraa Paehahati under the prescription in 1963 (see Table 5).

- Land 9: Occupied by Mareko Anakena, a Rapanui found on the list of Mo'orea. He gave it to his son Kaupari Arotea 'a Anakena.

- Land 11: After Mariu Nikonore's death, occupied for the first time by Catalina Te Kava Tutia, daughter of Matia Temanu (Land 10). In 1901, a legal ruling gave the land to Cécile, Delphine, and Honoré Manueono, the daughters of Timoteo Manueono and Anikete Harekirangi (see Table 7).

- Land 14: Occupied by Petero Tepuku (Land 19) after Tearahiva's death (1894). Then owned by Atiapoe Tepuku 'a Rehu (son of Tepuku) and finally, in 1951, by Maria 'a Rehu (daughter of Atiapoe) who received it under the prescription in 1971 (see Table 5).

- Five lands were sold by the Pamatai buyers of 1887 to Tahitians or Europeans descendants:

- Land 4: Sold by Onorato Maurata in 1903 to Taahitua Maihuti and to Leonard Alexandre in 1909.

- Land 6: Sold by Atiriano Pua to Edouard Atger, in 1909.

- Land 8: Sold by Karepare Aopero to Louis Tinau, in 1897.

- Land 13: Sold by Reone Tekena to Gustave Hennebuise, in 1905.

- Land 18: Sold by Timoteo Veroauka to Jean-Marie Cadousteau, in 1905.

It is interesting to note that none of these Rapanui men had descendants.

- Five lands were sold by people who reported having a family relationship with the former owner:

- Land 1: Sold by Poko 'a Repe in 1898 to Vairua 'a Tairua, claiming to be the brother (fêti $i$ i) of Hukihiva.

- Land 7: Sold by Maria Carmel Hanateina, claiming to be "first cousin" (fêti ' $i$ ) of Marceline Anatereau, Petero Mati's wife.

- Land 9: Sold by Kaupari Arotea 'a Anakena to Meou Lee in 1925, claiming to be a nephew of Terea Hute. 
- Land 24: Sold by sons of Naporeao Puna (Motu 'a Naporeo [Amaru Reoni], Tupuraa 'a Naporeo [Anne Marie] and Ahuura 'a Naporeo [Louise Ahupotu]), to Ernest Aubry in 1912 (see Table 5).

- Land 25: Sold by Maria Tepano to Ernest Aubry in 1905, claiming to be the widow of Tepano Hakarevareva (see Table 4).

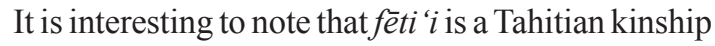
term to express the extended relationship of kinship.

- Finally, three lands were under administration of the Catholic Mission with documented permission coming from Rapa Nui.

- Land 10: Authorizations signed by Matias Hotu (Matia Temanu's grandson) in the following years: 1926 and 1951 (see Table 6).

- Land 12: Authorizations signed by Mateo Veriveri (Akutino Hereveri's grandson, son of de Moisés Tu'u Hereveri) in the following years: 1926, 1948, and 1959 (see Table 6).

- Land 16: Authorizations signed by Victoria Rapahango (great-niece of Antonio Aringa) signed in the following years: 1926, 1954, 1960, and 1966.

In all three cases, the Catholic Mission had Anne Marie Tupuraa Puna (Naporeo Puna's daughter) as an administrator of the land, who signed the registry documents in 1921. Then, her daughter, Marie Tupuraa Paehahati signed the registry documents in 1951.

During my research in Tahiti (2012-2013), I found information about these three descendants of the 1887 buyers, who maintained a sporadic but important correspondence from Rapa Nui to the successive Bishops of Tahiti (Hermel, Mazé, and Coppenrath). In addition to that, in 1942, priest Célestin Maurel wrote in the Church book that the Mission had sent money from the lease of land to the Rapanui heirs (Maurel 1942). However, it is unknown if this money actually reached the island.

It is interesting to note that the first letters to the Catholic Mission date back to 1926. During the same year, those 15 islanders traveled to Tahiti. In addition, the name Tupuraa appears in the description of this trip, a name which Mateo Veriveri would give to Father Sebastián Englert ten years later (1936).

The administration of these three lands was restored to the descendants during the $70 \mathrm{~s}$, partly thanks to the letters sent to the Mission. However, this process was not free of conflicts within the groups of heirs. A fourth land would be recovered during the 80 s for the Hito family after a trial. Interestingly, the Catholic Mission also administered a portion of this land.
Following the sales and subdivision by succession, it is clear that a gradual accumulation of land by some inhabitants of Pamatai, such as Emilio Paoa Make (son of Petero Make) and Marie Tupuraa Paehahati (granddaughter of Naporeo Puna) were among the Rapanui descendants. Also, Gustave Hennebuise, Ernest Aubry, and Jean-Marie Cadasteau were all among the Tahitians and the European descendants. These new owners, along with Bruno Oreare, sold the common land (the plots A, B, C, D, and the land between the sea and the road) to the Catholic Mission in 1916 (Maurel 1942).

This analysis shows that changes in land ownership were not simply due to purchases and the sale of land. Instead, they were a result of the activation of kinship ties in their extended versions ( $f \bar{e} t i{ }^{\prime} i$ ), which involved the transfer of rights and land occupation in the case of plots where land was not owned due to a lack of succession.

\section{6: Moana Schooner, an Exceptional Event}

For almost 70 years, under the pretext of leprosy, the Chilean administration banned the movement of islanders away from Rapa Nui. This established a regime of confinement ( $c f$. Foerster \& Montecino 2012) and a disruption of contact with Tahiti, preventing communication between the two communities. But, in 1926, the Tahitian schooner Moana stopped at Rapa Nui. The captain decided to hire and transport 15 persons to Tahiti (two European colonists and thirteen Rapanui people). They obtained permission from the Chilean Maritime Sub-delegate Carlos Recabarren by arguing that it was their intention to travel to Tahiti to sell the lands they owned there (see Figure 2). As such, this demonstrates knowledge about the lands of Pamatai and an interest to better understand the status of these properties.

Information about this trip, along with a list of travelers, is found in the documents of the Maritime Sub-delegate, and in the narration from Mateo Veriveri (Beriberi or Hereveri) to Sebastián Englert in 1936 (Englert 1948:385-407). During my Tahitian fieldwork in 2013, stories related to this trip were collected. These narratives were important to understanding the reality of Tahiti at the time, which was radically different to the reality of Rapa Nui.

According to Mateo Veriveri (Englert 1948:385407) the schooner stopped on Mangareva and at some atolls of the Tuamotus (Nuku Tavake, Manu, Hiku Eru) where the Rapanui worked in the care of animals and coconut harvesting. In Tahiti, they would later live between Pamatai and Pape'ete for five months. Fourteen of them returned to Rapa Nui in February 1927. Juan Ruko did not return (Recabarren 1927: Intendencia de Valparaiso vol.919 f22), because he had found work (Mateo Veriveri, cited in Englert 1948). 


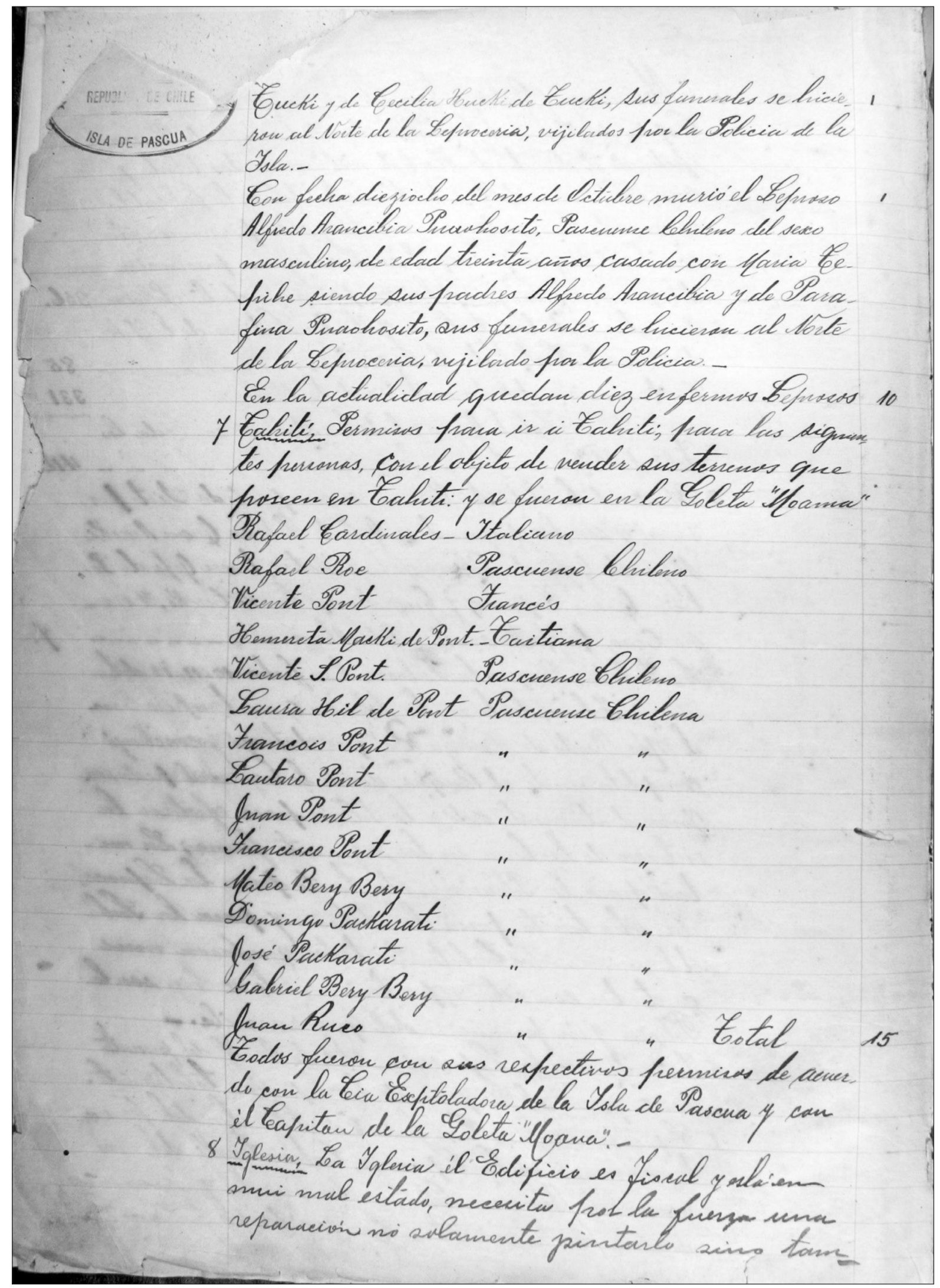

Figure 3. Permission for 15 Rapanui to travel to Tahiti. Carlos Recabarren, Memoria y Balance Anual 1926. Intendencia de Valparaíso Vol. 919 f2. 
"When Rapanui natives living in Tahiti realized that the Moana was in Papeete, they came to see us, to accompany us on the trip to Pamatai [...] A Rapanui woman came to us and said: come (to my house) let's all go to Pamatai [...] We stayed at the house of Rarato 'a, who is the husband of Tupuraa, who takes care of our land [...] Another day the daughter of my mother's brother came" (Narrative of Mateo Veriveri, in Englert 1948:399-400).

"My grandfather, Domingo Pakarati told me they came to Tahiti and stayed with his uncle. Here, my uncle Gabriel was sick, so they asked his uncle Andrés to sell his land to pay for the trip back to Rapa Nui. It was then that Andrés told them about [land] 20, it was of his sister, Mateo's mother [...] My uncle [Mateo Hereveri] told me that his uncle [Andrés] lived in [land] 12. He worked on the [land] 20 but he lived in [land] 12" (Judith Hereveri Pakarati, pers. comm., Pamatai 2012).

This trip is important for four reasons: 1) at least nine of the participants were direct descendants of buyers of 1887: Heremeta Make - daughter of Kinitino Make - his son Vicente Pont Make and his children; Mateo and Gabriel Veriveri, grandsons of Akutino Hereveri; and Juan Ruko, son of Kerekorio Tuteao Ruko. Add to this Domingo and José Pakarati, sons of a Tuamotu woman; and Rafael Roe (who was a child), for an eventual link with Terea Hute (Judith Hereveri Pakarati, pers. comm.); 2) it gave an opportunity to update kinship ties with the descendants of the diaspora (Mateo found the brother of his mother and the children of this brother); ${ }^{12} 3$ ) it allowed the Rapanui to make an appearance as heirs (Judith noted that Andrés indicated the land of his sister); and 4), it helped bequeath land administration (Mateo designated Maria Tupuraa as a caregiver) until they could return to Tahiti.

\section{Coming to Tahiti in Small Boats (1947-1958)}

After the Moana's trip, the only way to get to Tahiti was attempting perilous voyages in small boats. Eight attempts were made between 1944 and 1958. One was rescued at sea by an American cargo ship (1944), four boats were presumably wrecked, disappearing with their crew $(1948,1955,1956,1958)$, and only three $(1947,1954,1955)$ arrived and were able to land in Polynesia (Englert 1960; Peteuil 2004; Muñoz 2010). In total, 39 people tried to get to Tahiti, but only 18 returned to tell their stories, including Judith Hereveri's grandfather, who also participated in the trip of 1926.

With my fieldwork in Tahiti and with reports compiled by other researchers (Nègre 1956; Peteuil 2004; Stambuk 2010), I conclude that once survivors landed in Tahiti, the descendants of the original
Rapanui buyers of 1887 greeted them. Several of the survivors had some genealogical link to the inhabitants of Pamatai. ${ }^{13}$

André Nègre knew Pedro Chavez, Aurelio Pont, and Felipe Teao in Tahiti. They participated in the escape of 1954. Nègre (1956:193) explained that they were living in Pamatai, with an "old Rapanui man becoming Tahitian." The same information was conveyed by Aurelio fifty years later.

\begin{abstract}
"In Papeete the police asked if we had relatives, I said yes, they are the first cousins of my father. You're Juan? He asked me. No, I'm not Juan, I'm Aurelio, the eighth child. He mistook me for my brother, who had gone to Tahiti with my father and my mother when he was three or four years old. Before, when Easter Island was a French colony, boats would come and go. So, my grandfather Vicente Pont arrived on the Island. My uncle wanted to adopt Juan, but my mother did not accept him and we returned to Rapa Nui" (Aurelio Pont, in Štambuk 2010:210).
\end{abstract}

Aurelio Pont was the grandson of Heremeta Make. In his story he identified a first cousin of his father, who received him in Tahiti (probably Emilio Make) and referred to the journey of their parents and a younger brother. Aurelio undoubtedly referred to the schooner Moana.

\section{"My grandfather, Domingo Pakarati told me he went to Tahiti. He went in a boat with two children! Diego and Tato. The wind took them up to Reao. He told me about Tahiti. Here he found an aunt, one sister of his mother. When she knew that they were in Tahiti she came to Pape'ete to see them. She asked him to leave her the children, but he did not give them to her." (Judith Hereveri Pakarati, Pamatai 2012).}

These stories illustrate that there were active ties and obligations linked to kinship between the new Rapanui migrants and the Rapanui diaspora descendants (adoption intentions included). These kinship links would later help when claims of ownership began in the 1970 s.

\section{Conclusions: Migration, Kinship, and Lands}

When the new generation came to Tahiti, they found that the land they believed was theirs by inheritance was, in fact, owned by others. It is important to mention that the policy of isolation of the Chilean State on Easter Island had prevented the Rapanui from having any opportunity to know about the descent lines of their relatives in Tahiti and the successive changes in ownership. For some Rapanui people, the 25 buyers 
of 1887 are the owners forever and the "true heirs". This has led several Rapanui to claim the property of Pamatai. This triggered a series of family and legal conflicts.

In this paper, I demonstrated that an important aspect of the lands of Pamatai was in the hands of the descendants from the Rapanui diaspora of 1871, until well into the twentieth century, as well as the fact that five lines of descent have been perpetuated until today. My research identified five cases of genealogical links between the first buyers and current families on Rapa Nui (Ruko, Hereveri, Hotu, Pont, and Hito).

Rapanui strategies to recover the land after the 1970s are based on two principles of Polynesian kinship (or a classic Polynesian kinship group theory): the "principle of bifurcation" and the "rights of primogeniture" (Bambridge 2009). With that the Rapanui people evoked a "non-negotiable selfdefinition status" (Dousset 2003; Saura 2008) of "legitimate genealogical heirs".

In the first case, it was important to find a relative who was serving as a genealogical link between the claimant and the former owner. This was intended to show that current occupants had no legitimate rights. These rights were theoretically transferred along lateral lines, in other words, to brothers and the descendants of the former owner.

Example:

"Here, I am Victoria, daughter of PAPA A RINGA, daughter of A RINGA.

That is why I ask you, my Father, [about] the land of PAPA Ringa. Is it in good condition? I'm here, the true blood of Papa Ringa.

How it that?

The father is Paoa. Paoa had two children, URE A

Ringa, the matahiapo, and VERITAEPU, the sister.

Ure a Ringa had Huri, Papa Aringa. Papa Aringa did not have children.

HAE VERITAEPU had Vitorio, Vitorio had Rapahango, Rapahango had Vitoria [sic]. Vitoria [Rapahango] had Rike. Descendant of Victoria, Rapahango of Uita of Veritaepu of Paoa ... This is our genealogy." (Letter of Victoria Rapahango to the Bishop of Tahiti, September 18 1926. ArchEvêché:I 24-7-1).

In these cases, family memories were key to establishing links to the land. But in other cases, past memories created more confusion. On occasion, Tahitian names were taken as Rapanui surnames. Also, land was, in fact, sold or assigned to others in court.

For example there is a claim on Land 15, given by Pakarati Rengavaruvaru to his godson Pakarati Nuihiva Tauripa. On Rapa Nui, he was associated with Nicolas
Pakarati Ure Potahi, the founder of the Pakarati family. But Pakarati is a Tahitian form of Pancrace's first name (Englert 1948:53; McCall 1986:14). The claim of Land 11 is similar: it is said that Mariu Nikonore was the same person as Petero Manuheuroroa from Rapa Nui (see Note 8).

The second strategy involved the descent group of the claimant. A person declared themselves as the only legitimate heir to be the closest living descendant of the former owner. In these cases, information about the properties and contact with the Church was strategically hidden.

For example, Mateo Veriveri administered his grandfather's (Akutino Hereveri) land until his death (in 1970). Then, it was his younger brother, Miguel Veriveri, who claimed property rights. However, Miguel faced trial with his nephews, who, knowing more about French civil code, demanded to be included in the property rights. In 1976, the land of Akutino was divided into six plots, corresponding to his six grandchildren who had descendants, including Mateo and Miguel.

A claim was based on the "precise" fixation of genealogies and the rectification of family names. This had real consequences in the standardization of a patronymic writing considering the "truth name". This "truth" was the names on the land map of 1888 (see Figure 2), because of this, the family name Veriveri was changed to Hereveri in 1976. Secondly, it caused a manipulation of family memories, in order to have a genealogical discourse that served to validate a de facto inheritance.

Example 1:

"Whenever I heard Marta Niarez, my mother, talk about the land that belonged to the family and that was in Tahiti (Pamatai) [...] Marta Niarez heard her uncle Mateo Tauhan [sic] had acquired land in Tahiti [...] Pua Moto, sister of Mateo Hau Tau [sic] returned from Tahiti to die in Easter Island. She confirmed that Mateo [...] owned the land and when he died, Pua should receive the land as an heiress [...] Pua Motu is the grandmother of Marta Niarez [...] Makarita Renkamaruaki a Niarez has a property title. Before dying in the hospital, she bequeathed it to Marta Niarez, her niece." (Declaration of Maria Antonia Pate Niare to Father León Lemouzef de Marle. July 27, 1976, Hanga Roa. ArchEvêché: unclassified document).

Example 2:

"This declaration aims at finding some interesting facts appearing in the genealogy of Napoleon Paoa A Avaka [sic], related to the land in Pamatai, Tahiti [...] May the maternal grandfather of the applicant be 
found in the Registry with the surname Pate Vaka. He should actually be named and registered as Timoteo Vaka Tearahiva, because he was the legitimate son of Domingo Vaka Tuku Onga and Margarita Tearahiva." (Declaration of Napoleon Avaka Paoa in Easter Island's Court. May 5, 1977. From Judith Hereveri Pakarati's private archive, Pamatai).

For Franco-Tahitian courts, such statements had no legal relevance. Instead, for example, it was like a succession via a legal will. The only argument that proved a succession of rights and finally a return of lands was in the letters sent to the Catholic Mission to manage the land. Here lies the importance of the 1926 trip. The maintenance of this contact with the Church of Tahiti, although sporadic, was a key to legitimize restitution claims in the 70s (i.e. cases of Rapahango, Hereveri, and Hotus).

Raymond Firth (1957) explains that property rights in Polynesia were expressed and validated in residence. In this case, Rapanui people did not have the opportunity to live in Tahiti (apart from the brief moment of 1926 and/or the cases of Juan Ruko's death in Pamatai in 1927 and Pedro Chavez, who died in Pape'ete in 1998). So they gave the administration (but not the property) of the land to others, including the Catholic Church. This shows an interesting articulation of the Polynesian concept of land, the notion of personal property, and their use of the foreign civil code in the conception of land.

This articulation, not always harmonious, was disappointing to some Rapanui people. While some had family problems, others had legal problems with the new owners.

For the Rapanui people, the lands of Pamatai evoke a long history of memorial links between Easter Island and Tahiti and the banned traveling for years, appealing to a widespread diaspora history. Family ties were "manufactured" theoretically to legitimize land rights and ownership, an issue that is still being debated today. Thus, the memory of the lands and the hypothetic genealogical links with a diaspora history allows us to understand the links of Rapanui people with Tahiti and the second migration process that started in 1968.

\section{Acknowledgements}

I wish to express my gratitude to Judith Hereveri Pakarati, Moisés Hereveri Pakarati, Adriana Laharoa, Regino Tuki Hotus, Matias Hotu Hey, Maria Rapanui Haoa, Gilles Bordes, Delphina Tikare, Elvira Robson, Jeanne Tekurarere, frère Gaspar (archivist of the Bishop of Tahiti), and Sylvie Bessert (Office of Land in Tahiti) for their help during my fieldwork in Tahiti. I also want to thank Dale Simpson, Cristián Moreno Pakarati, and an anonymous reviewer for their valuable comments. I thank CONICYT (Chilean National Commission for Science and Technology) and the French Embassy in Chile for my scholarship to pursue postgraduate studies in France and to the Centre for Research and Documentation on Oceania (CREDO UMR 7308) and the École des Hautes Études en Sciences Sociales (EHESS) for their financial assistance to cover my fieldwork expenses.

\section{Notes}

1. The interviews were conducted in Spanish or in French. The majority of the documents mentioned are written in Spanish or in French, only a few are written in Tahitian or Rapanui language. Translation of these documents was done by the author with the help of Judith Hereveri, a Rapanui resident in Tahiti.

2. A first group left Rapa Nui in 1944. They set a course for the Chilean mainland (Englert 1960; McCall 1997; Peteuil 2004; Muñoz 2010).

3. It is important to mention the pernicious demographic effects caused by the blackbirders of Callao, Peru between 1862 and 1863. The most complete work on this topic is Maud (1981). For the particular case of Rapa Nui, the most detailed work is of McCall (1976b). In another article, McCall (1996:27) thought that between 1862 and 1868 the population in Easter Island had diminished between $50-75 \%$.

4. Eneriko Tori ( 1852-1919) and Andrés Avaka ( 18591929 ) are in Salmon's census of 1886 (McCall 1976a:310-318). Tori appears in the list of those who received a scapulary of George Eich's on January 10, 1898 (Cools 1975:ms35-46:286-290). In 1900, Tori was married in Rikitea and would go on to father several children in Mangareva. Andrés Avaka was married to Veronike Keremuti in Pamatai. Veronike was a daughter of Eukenio Keremuti and Marie Keremiko Haka, both were Brander's Rapanui workers. Veronike was born in 1873 on Mahina.

5. At least three of them had been born in Tahiti: Moisés Jacob Tu'u Hereveri (1873-1925) and Veronique Ohititeairangi (Verónica Mahute) (1874-1947), both born in Haapape; and Matias Hotu (1886-1951) born in Pamatai. Veronica Mahute would be the wife of "King" Riro 'a Ngaure (Riro 'a Kaina), and Tu'u Hereveri would be declared "King" at the beginning of the 20th century (cf. Vives Solar 1920; Estella 1920; Moreno Pakarati 2011).

6. Possibly, Reone Terongo with his adopted son: León Laharoa. Kerekorio Tuteao, his wife and four children, Veronica Ihumako with her young son Tepano Ihu Taha, and Lataro Tumatahi.

7. A detailed summary can be found in Muñoz (2014).

8. On Rapa Nui, Mariu Nikonore has recently been associated as the first husband of María Angata (Hotus et al. 1988, 2007). However, in the Rikitea records, María Angata's husband is identified as Daniel Manuheuroroa or Petero Manuheuroroa. According to McCall (1986), Manuheuroroa was killed in Mangareva, which was confirmed by informants of Stambuk (2010:33). According to them, this would have happened in 1873. In the documents collected in 2012 and 2013, the only person with the name Mariu is Mariu Aroarua, who died in Pamatai in the year 1894. 
9. On Rapa Nui, León Laharoa is remembered as the adopted son (poki hāyai) of Reone Terongo. The story explains that he went with him to Rapa Nui, when León was still a child. León Laharoa was born in Tahiti, probably in 1894 and he died in Rapa Nui in 1976. He was the son of Petero Raharoa and Teuna Tepa (a Tahitian woman). Petero appears in various documents found in the archives of Pape "ete with different names: Petero a Kinitino, Petero Auaroa, Petero Make, and/or Poingo Make. According to Hotus et al. (1988, 2007), Petero Raharoa was a son of Raharoa and Maria Pua a Vave. She was the wife of Kinitino Make, and the mother of all the Make family of Pamatai, including Heremeta Make, wife of Vincent Pont. Thus, Petero Raharoa was a half-brother of Heremeta Make (see Table 6 \& Table 7).

10. Joseph Paehahati was born in Haapape in 1873. His parents were Petero Paehahati and Maria Turu; both were Brander's Rapanui workers.

11. The Prescription trentenaire is an article in the French civil code that regulates land tenure. It states that a person who has lived and worked on a land for a period of 30 years may request to be recognized as its owner (Davio \& Tevane 1997).

12. He is Andrés Manu Avaka (see Note 4) and his daughter, Ioana Manu Vaka, was born in Pamatai (1892-1951).

13. An article on this subject is in preparation.

\section{References}

Agnew, V. 2005. Diaspora, Memory and Identity. A Search for Home. Toronto: University of Toronto Press.

Anguita, P. 1986. La migration Rapanui vers Tahiti et Mangaréva (1871-1920). Unpublished Masters Thesis, University of Paris.

Baessler, A. 1900. Neue Südsee-Bilder. Berlin: Verlag Von George Reiner.

Bambridge, T. 2009. La terre dans l'archipel des Australes. Étude du pluralisme juridique et culturel en matière foncière. Paea, Tahiti: Au Vent des Iles.

Barré, J-F. 1987. Tahiti, les temps et les pouvoirs. Pour une anthropologie historique du Tahiti post-européen. Paris: OSTROM.

Conte, J. 1994. Isla de Pascua: horizontes sombrios y luminosos. Santiago: Centro de Investigación de la Imagen.

Cools, A. 1973. L'île de Pâques et la Congrégation des Sacrés Cœurs. Documentation. Rome, Italy. Unpublished document.

1975. Appendix. L'île de Pâques et la Congrégation des Sacrés Cœurs. Documentation. Rome, Italy. Unpublished document.

Clifford, J. 1994. Diasporas. Cultural Anthropology Vol. 9(3):302-338.

Davio, M. \& M. Tevane. 1997. Le problème foncier en Polynésie française. Tahiti-Pacifique Magazine 77. http://www.tahiti-pacifique.com/archivesTPM/07709. html

Dousset, L. 2003. Indigenous mode of representing social relationships: a short critique of the 'genealogical concept'. Australian Aboriginal Studies 1:19-29.

Englert, S. 1948. La tierra de Hotu Matu'a. Historia, etnología y lengua de Isla de Pascua. Chile: Padre las Casas: Editorial San Francisco.

1960. Aventuras marinas de nativos de Rapa Nui. Revista de Marina 76:465-475.
Estella, B. 1920. Los misterios de la Isla de Pascua. Santiago: Imprenta Cervantes.

Fischer S.R. 2005. Island at the End of the World. The Turbulent History of Easter Island. London: Reaktion Books.

Firth, R. 1957. A note on descendent groups in Polynesian. Man 57(2):4-8.

Foerster, R. \& S. Montecino. 2012. Rapa Nui: la lepra y sus derivados. In Escriturasamericanas. Departamento de Filosofía, UMCE 1:270-353.

Gossler, C. 2005. The Social and Economic Fall of the Salmon/Brander Clan of Tahiti. The Journal of Pacific History 40(2):193-212.

Hotus, A. \& el Consejo de Jefes Rapa Nui. 1988. Te Mau Hatu o Rapa Nui. Los Soberanos de Rapa Nui. Pasado, presente y futuro.

2007. Te Mau Hatu o Rapa Nui. Los Soberanos de Rapa Nui. Second Edition. Santiago: Editorial Edición.

Maud, H. E. 1981. Slaves in Paradise: the Peruvian labour trade in Polynesia, 1862-1864. Canberra: Austalian National University Press.

Maurel, C. 1942. Journal du Père Célestin. Manuscript. Tfa Pam 6-28: ArchEvêché de Pape'ete.

Messenger de Tahiti. Editions of October 12, 1872; May 22, 1872; November 9, 1877.

Moreno Pakarati, C. 2011. El poder político nativo en Rapa Nui tras la muerte de los últimos 'ariki mau. In La compañia explotadora de Isla de Pascua. Patrimonio, memoria e identidad en Rapa Nui. C. Cristino \& M. Fuentes (eds.): 53-73. Concepción: Ediciones Escaparate.

Muñoz, D. 2010. Au-delà de l'île de Pâques. De l'insularité et des flux dans l'identité rapanui contemporaine. Unpublished Masters Thesis, EHESS, Paris.

-2014. Las tierras rapanui de Pamatai (Tahiti). Estudio genealógico y de propiedad. Revista Apuntes del Museo 3:31-72. Museo Antropológico R.P Sebastián Englert.

McCall, G. 1976a. Reaction to disaster: Continuity and Change in Rapanui Social Organization. Unpublished PhD dissertation: Australian National University. -1976b. European Impact on Easter Island: Response, Recruitment and the Polynesian Experience in Peru. The Journal of Pacific History 11(2):90-105.

-1986. Las fundaciones de Rapanui. Easter Island: Museo Antropológico R.P Sebastián Englert.

1996. El Pasado en el presente de Rapanui (Isla de Pascua). Etnografia. Sociedades indigenas contemporáneas y su ideología. Culturas de Chile Vol.1:17-45. J. Hidalgo, V. Schiappacasse, H. Niemeyer, C. Aldunate \& P. Mege (eds). Santiago: Editorial Andrés Bello.

1997. Rapanui wanderings: Diasporas form Easter Island. In Easter Island in Pacific Context South Seas Symposium. C. Stevenson. G. Lee \& F. Morin (eds.): 370-378. Los Osos: Easter Island Foundation.

Nègre, A. 1956. L'Odyssée du San Padro. De l'île de Pâques à Tahiti. Paris: A. Sorel de Neufchateau Editions.

Peteuil, M-F. 2004. Les évadés de L'île de Pâques. Loin du Chili, vers Tahiti (1944-1958). Paris: L'Harmattan.

Pinart, A. 1999 [1878]. Voyages à l'île de Pâques. Bulletin de la Société des Etudes Océaniennes 281-182:51-76.

Recabarren, C. 1926. Permisos para ir a Tahiti. Memoria y Balance Anual año 1926. Intendencia de Valparaíso Vol. 919 f 2: National Archive of Chile.

1927. Permisos para ir a Tahiti. Memoria y Balance Anual año 1927. Intendencia de Valparaíso Vol. $919 \mathrm{f}$ 22: National Archive of Chile. 
Safran, W. 1991. Diaspora in modern societies: Myths of homeland and return. Diaspora: A Journal of Transnational Studies 1:83-99.

Saura, B. 2008. Les généalogies de Rurutu sont-elles vraies? Ou comment on écrit l'histoire en Polynésie. Bulletin de la Société des Etudes Océaniennes 312:37-62.

Stolpe, H. 1899. Ueber die Taetowierung der OsterInsulaner. Germany: Friedländer.

Štambuk, P. 2010. Rongo: la historia oculta de Isla de Pascua. Santiago: Editorial Pehuén.
Toro, P. 1893. Informe de la estadía de Pedro Pablo Toro, que hiciera al Ministerio de Colonización. Isla de Pascua. Memoria del Ministerio de Culto i Colonización en 1892: 187-206. Library of Chilean Congress.

Vives Solar, J.I. 1920. El último rey de Rapa-Nui. Revista Sucesos 932:no page number.

This article has been peer-reviewed. Received 16 August 2015; accepted 21 September 2015. 